\title{
Gleb Nikolayevich Baturin (On His 80th Birthday)
}

DOI: $10.1134 / \mathrm{S} 0001437011010206$

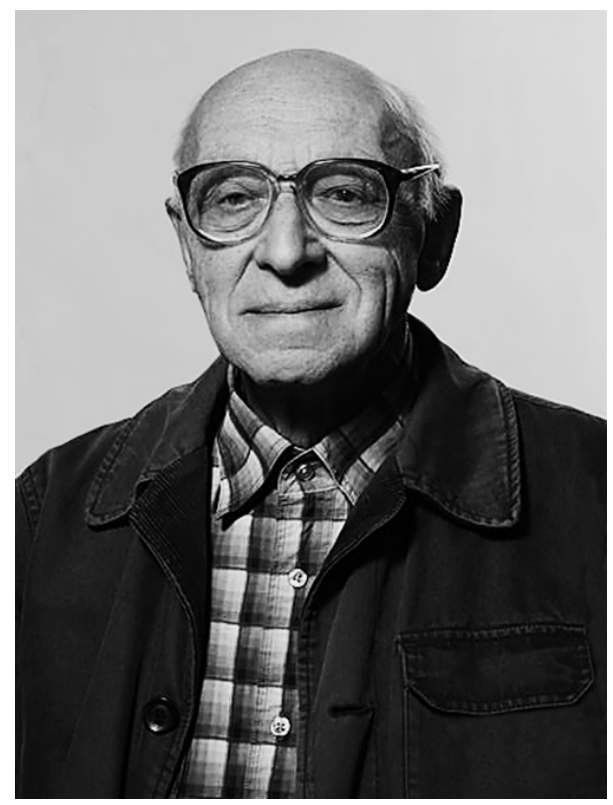

December 14, 2010, is the day of the 80th birthday of Doctor of Geological-Mineralogical Sciences, Professor, Honored Scientist, Chief Researcher of the Shirshov Institute of Oceanology of the Russian Academy of Sciences, and Editorial Staff Member of the Journal Oceanology Gleb Nikolayevich Baturin.

G.N. Baturin graduated from the Institute of Orientalism and the National Extramural Polytechnic Institute of Moscow. In the beginning of his scientific career, he worked in the countries of the Middle East and took part in geological expeditions on the Kalyma River, in Tuva, Kalmykia, and Ukraine. From 1960 to 1963, he worked at the National Institute of Mineral Resources and researched sediment deposits of uranium. In 1963, he entered the postgraduate course at the Institute of Oceanology of the Russian Academy of
Sciences. In 1967, he was awarded a candidate degree and in 1975 a doctorate degree. These works were devoted to the geochemistry of uranium and the genesis of phosphate rocks. Gleb Nikolayevich Baturin took part in many expeditions in the Pacific, Atlantic, and Indian Oceans as well as the Black, Aral, and Baltic Seas.

One of the most important results obtained by G.N. Baturin's was the first in the USSR study of the composition of metal-bearing dregs of the rift of the Red Sea; the world first finding of sulfide ore mineralization in the rift of the Indian Ocean and the prediction of the global ore-bearing rift zones of the ocean; and the first finding in the ocean of modern phosphate rocks, on which a new theory of their origin was created. The result of this work was the phenomenon of the formation of modern phosphate rocks in the upwelling zones on the ocean shelves (the Baturin effect).

G.N. Baturin was directly engaged in the discovery and research of the phosphate rock deposit in the shelf of Namibia, the largest in the ocean, with ore reserves of about 4 billion tons. The sphere of G.N. Baturin's scientific interests included the research of bottom sediments, pore solutions, and water suspensions and volcanic material coming into the ocean, which made it possible for him to reconstruct to a fuller measure the picture of the ore-forming processes.

G.N. Baturin is the author of over 400 scientific publications, including 10 monographs, two of which have been translated into English and one into Chinese. At present, Gleb Nikolayevich is actively working along the following lines: iron-manganese oregenesis in the ocean, the composition and conditions for the formation of phosphate rocks, metal-bearing marine carbon sediments, conditions for the concentration of uranium and rare elements in sediments, and the role of material as the source of metals in the ocean. 